\title{
Chemical disinfection of combined sewer overflow waters using performic acid or peracetic acids
}

Chhetri, Ravi Kumar; Thornberg, Dines; Berner, Jesper; Gramstad, Robin; Öjstedt, Ulrik; Sharma, Anitha Kumari; Andersen, Henrik Rasmus

Published in:

Science of the Total Environment

Link to article, DOI:

10.1016/j.scitotenv.2014.05.079

Publication date:

2014

Link back to DTU Orbit

Citation (APA):

Chhetri, R. K., Thornberg, D., Berner, J., Gramstad, R., Öjstedt, U., Sharma, A. K., \& Andersen, H. R. (2014). Chemical disinfection of combined sewer overflow waters using performic acid or peracetic acids. Science of the Total Environment, 490, 1065-1072. https://doi.org/10.1016/j.scitotenv.2014.05.079

\section{General rights}

Copyright and moral rights for the publications made accessible in the public portal are retained by the authors and/or other copyright owners and it is a condition of accessing publications that users recognise and abide by the legal requirements associated with these rights.

- Users may download and print one copy of any publication from the public portal for the purpose of private study or research.

- You may not further distribute the material or use it for any profit-making activity or commercial gain

- You may freely distribute the URL identifying the publication in the public portal 


\title{
Chemical disinfection of combined sewer overflow waters using performic acid or peracetic acids
}

\author{
Ravi Kumar Chhetri ${ }^{\mathrm{a}}$, Dines Thornberg ${ }^{\mathrm{b}}$, Jesper Berner ${ }^{\mathrm{c}}$, Robin Gramstad ${ }^{\mathrm{d}}$,

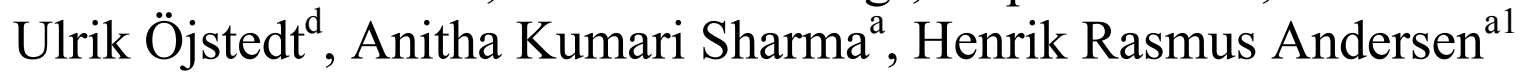 \\ a Department of Environmental Engineering, Technical University of Denmark, Bygningstorvet, Building \\ 115, 2800 Kgs. Lyngby, Denmark. ${ }^{1}$ Corresponding author: Henrik@ndersen.net. \\ ${ }^{\mathrm{b}}$ Udviklingssamarbejdet, c/o, Lynettefællesskabet, Refshalevej 250, 1432 Copenhagen, Denmark. \\ ${ }^{\mathrm{c} K e m i r a}$ Water Danmark A/S, G-vej 3, 2300 Copenhagen, Denmark. \\ ${ }^{\mathrm{d}}$ Kemira Kemi AB, Industrigatan 83, Box 902, 25109 Helsingborg, Sweden.
}

\section{Highlights}

* Performic and peracetic acid disinfection of combined sewer overflow was evaluated

Sewer overflow water for laboratory studies was made with diluted raw wastewater

The bathing water indicator E. coli was always easier to disinfect than Enterococcus

Peracetic acid required long contact time ( 2 ppm, 6 h) for efficient disinfection

Performic acid was short lived but potent, efficient disinfection by 2 ppm, 20 min

Abstract We investigated the possibility of applying performic acid (PFA) and peracetic acid (PAA) for disinfection of combined sewer overflow (CSO) in existing CSO management infrastructures. The disinfection power of PFA and PAA towards Escherichia coli (E. coli) and Enterococcus were studied in batch-scale and pre-field experiments. In the batch-scale experiment, $2.5 \mathrm{mg} \cdot \mathrm{L}^{-1}$ PAA removed approximately $4 \log$ unit of E. coli and Enterococcus from CSO with a 360 min contact time. The removal of E. coli and Enterococcus from CSO was always around or above $3 \mathrm{log}$ units using 2-4 $\mathrm{mg} \cdot \mathrm{L}^{-1} \mathrm{PFA}$; with a $20 \mathrm{~min}$ contact time in both batch-scale and prefield experiments. There were no toxicological effect measured by Vibrio fischeri when CSO was disinfected with PFA, a slight toxic effect was observed on CSO disinfected with PAA. When the design for PFA based disinfection was applied to CSO collected from an authentic event, the disinfection efficiencies were confirmed and degradation rates were slightly higher than predicted in simulated CSO.

Keywords: disinfection, combined sewer overflow, peracetic acid, performic acid; chemical disinfection; stormwater treatment, Escherichia coli, Enterococcus. 


\subsection{INTRODUCTION}

Combined sewer overflow (CSO) is a well-known phenomenon in combined sewer systems where wastewater and rain water are transported in the same sewers. CSOs occur when the rainfall exceeds the design capacity of sewer systems and needs to be discharged to surface water near cities, either directly, or after a short retention in detention tanks or outfall pipes (see graphical abstract, supplementary Figure S1). Discharge of untreated CSOs deteriorates the quality of receiving waters, since CSOs contain a variable mixture of rain water, raw sewage, watershed runoff pollutants, variable pathogenic organisms, viruses, cysts, suspended solids, chemicals and floatable materials (USEPA, 1999). In recent years, the effect of CSOs on water bodies used for recreational purpose has caught a lot of attention in Europe. Particularly the dedication from 2002 of Copenhagen harbor for recreational purposes including swimming and water sports has yielded an economically significant added service and tourism industry to the harbor area. Corresponding economic loss when CSO events close the harbor for bathing has inspired construction of significant retention basins which should limit the CSO events frequency, but due to the climate change related increased number of extreme rain events in 2000-2011 20, rain events caused temporary closing of the bathing (NYC Global Partners, 2011).

According to European Union directive 2006/7/EC for the good quality of bathing water, the number of indicator organisms should not exceed $500 \mathrm{mpn}$ E. coli per $100 \mathrm{~mL}$ and $200 \mathrm{mpn}$ Enterococcus per $100 \mathrm{~mL}$ water intended for recreational purposes based upon 95 percentile evaluation. For bathing water of sufficient quality, the number of indicator organisms should not exceed 500 E. coli per $100 \mathrm{~mL}$ and 185 Enterococcus per $100 \mathrm{~mL}$ water intended for recreational purposes based upon 90 percentile evaluation (Directive 2006/7/EC, 2006). Bathing water quality can be maintained by disinfecting the CSOs, but the disinfection capacity of a chemical depends on the concentration and the contact time (see supplementary Figure S1). Disinfection of CSOs can be achieved in the existing sewer systems by adding a disinfectant at the beginning of the outlet pipe or before the detention tank. The amount of disinfectant to be added will depend on the quality of CSO and the available residence time in the system.

According to Tchobanoglous et al. (2003), requirements of an ideal disinfectant should guarantee the maximum efficiency in pathogenic microorganism removal, without generating toxic and undesirable by-products. In addition, it should be inexpensive and technologically compatible (Tchobanoglous et al., 2003). There are various well known disinfection technologies from the water industries (White, 1992), which could be used to reduce the contamination by microorganisms from CSO events, before their discharge to receiving waters (Tchobanoglous et al., 2003). The most common options are disinfection using chlorine compounds, ozone, and UV. However, there are some important differences between disinfection of CSO compared to disinfection of wastewater; namely that CSO events only occur a few times per year, compared to the year round continuous need for disinfection of wastewater. Furthermore, both the quality and the quantity of CSO needed to be disinfected changes rapidly during a CSO event, therefore the disinfection of CSO requires that the disinfectant is robust enough for water quality changes and that the dose of disinfectant can be changed rapidly.

Chlorine is the most well-known and widely used disinfectant because of its high biocide power (Tree et al., 2003; White, 1992). However, the use of chlorine is decreasing in the water industry because of the formation of toxic, mutagenic, and carcinogenic chlorinated by-products (Bayo et al., 2009; Bellanca and Bailey, 1977; Glaze and Henderson IV, 1975; Hrudey and Charrois, 2012; Nurizzo et al., 2005; Watson et al., 2012). Additionally, chlorine is less suitable for CSO disinfection than most other water types due to the high sensitivity of efficiency with $\mathrm{pH}$ variations and the formation of chloramines with nitrogen compounds in the raw water component of CSO. Chloramines are acutely toxic to many aquatic organisms (Pasternak et al., 2003). An alternative to 
chlorine is chlorine dioxide. The disinfection power of chlorine dioxide is not sensitive to $\mathrm{pH}$ variations and it doesn't react with ammonia and amino groups (Huang et al., 1997). Chlorine dioxide is used in installations for CSO disinfection in the USA. The disadvantages of chlorine dioxide are the higher capital cost of installation compared to chlorine (White, 1992), and the formation of the residual product, chlorite, which has a medium toxicity to aquatic organisms that requires consideration (Svecevicius et al., 2005). UV radiation and ozone are also efficient disinfection methods, but they are complex and expensive to install for treatment of CSO. Ozone is a very efficient disinfectant, however, the high cost of the generator and equipment make it unsuitable for disinfection of CSO events, which only occur a few times in a year.

Two organic peroxides, peracetic acid (PAA) and performic acid (PFA), which fulfil the disinfectant requirements given by Tchobanoglous et al. (2003) have emerged as alternatives to the chlorine compounds for disinfection of wastewater treatment plant (WWTP) effluents. PAA is a strong disinfectant with a wide spectrum of antimicrobial activity that was introduced to wastewater treatment around 15 years ago (Antonelli et al., 2006; Falsanisi et al., 2006; Kitis, 2004; Koivunen and Heinonen-Tanski, 2005). Commercially available PAA, is available as an acidic quaternary equilibrium mixture of peracetic acid (PAA), hydrogen peroxide, acetic acid, and water:

\section{$\mathrm{CH}_{3} \mathrm{COOH}+\mathrm{H}_{2} \mathrm{O}_{2} \rightleftharpoons \mathrm{CH}_{3} \mathrm{CO}_{3} \mathrm{H}+\mathrm{H}_{2} \mathrm{O}$ (Eq. 1)}

The degradation products are acetic acid, hydrogen peroxide, and water. Acetic acid is biodegraded further to carbon dioxide and hydrogen peroxide degrades to oxygen and water; neither of which are considered toxic to aquatic life (Liberti and Notarnicola, 1999). However, as hydrogen peroxide remains in the treated water its toxicity to organisms in the receiving water needs consideration. Effect concentrations for aquatic organisms are reported as low as $2.4 \mathrm{mg} / \mathrm{L}$ (ECETOC, 1993).

Performic acid (PFA) has emerged as a well-known disinfectant in the medical field and food industry (Gehr et al., 2009). In recent years, PFA has been used to disinfect primary and secondary WWTP effluents and can efficiently remove fecal coliforms at low doses (Gehr et al., 2009; Ragazzo et al., 2013). PFA is an unstable product and needs to be generated on-the-spot, when needed, as a quaternary equilibrium mixture of performic acid (PFA), formic acid (FA), hydrogen peroxide and water:

$$
\mathrm{CH}_{2} \mathrm{O}_{2}+\mathrm{H}_{2} \mathrm{O}_{2} \rightleftharpoons \mathrm{CH}_{2} \mathrm{O}_{3}+\mathrm{H}_{2} \mathrm{O} \text { (Eq. 2) }
$$

The degradation products of PFA are formic acid and water. Formic acid is not toxic to aquatic fauna and easily biodegradable (Gehr et al., 2009; USEPA, 2001). Both organic peroxides PAA and PFA have shown high disinfection efficiency on treated wastewater effluents, but in a recent literature search, PAA and PFA have not been found to have been tested or used to disinfect CSOs.

Both PAA and PFA are used for disinfection of a few WWTP effluents in Denmark and it is known that the cost is about $15 € / \mathrm{kg}$ (active substance) which is about twice the cost of sodium hypochlorite (FRODO, 2014). Installations for dosing the chemicals have annualized capital costs around $2100 € / y$ for PAA and sodium hypochlorite, but around $12,000 € / y$ for PFA due to the complication of synthesizing PFA onsite (FRODO, 2014).

The aim of this study was to investigate the feasibility of applying PAA and PFA as chemical disinfectants for the disinfection of CSOs in retention basins or through long sea outfall pipes. The idea is to use the retention time in the retention basins or long sea outfall pipes to have a controlled minimum contact time. In order to discuss this, this study investigated (i) degradation rates of PAA and PFA in CSOs of variable quality, (ii) disinfection efficiency of PAA and PFA on E. coli and Enterococcus in CSOs, and (iii) residual toxicity of CSO treated with either PAA or PFA. 


\subsection{METHODS}

\subsection{Chemicals}

Formic acid 85\% w/w, hydrogen peroxide (50\% w/w), ABTS (2, 2''-azino-bis [3ethylbenzothiazoline-6-sulfonic acid] diammonium salt) sodium thiosulphate, sulphuric acid (95\%), and catalase from bovine liver (2,000-5,000 units/mg protein) were all purchased from SigmaAldrich (Brøndby, Denmark). All chemicals were reagent grade. PAA (CAS no: 79-21-0) solution containing 30-40\% w/w of technical grade disinfectant was supplied by Sigma-Aldrich (Brøndby, Denmark). From this, a working solution of $1 \mathrm{~g} \cdot \mathrm{L}^{-1}$ PAA was made, which was quantified daily by dilution of subsamples to $2 \mathrm{mg} \cdot \mathrm{L}^{-1}$ and analyzed using the method described below for PAA.

PFA was prepared in two steps, each time an experiment was performed. First, $11 \mathrm{~mL}$ of formic acid $(85 \% \mathrm{w} / \mathrm{w})$ was mixed with $1.0 \mathrm{~mL}$ sulphuric acid $(95 \%)$ in a glass test tube. Secondly, $0.9 \mathrm{~mL}$ of the this mixture was added to $1.1 \mathrm{~mL}$ of hydrogen peroxide $(50 \% \mathrm{w} / \mathrm{w})$ in a $5 \mathrm{~mL}$ test tube, immersed in a water bath controlled at $20^{\circ} \mathrm{C}$. The product was allowed to react for $10 \mathrm{~min}$ before the product was immediately used for experiments and quantified, in parallel, by dilution ( $125 \mu \mathrm{L}$ to $100 \mathrm{ml}$ ) of a subsample in demineralized water, to yield a solution of $2 \mathrm{mg} \cdot \mathrm{L}^{-1}$ which was analyzed using the method described below for PFA.

\subsection{Simulated CSO}

The concentration of raw wastewater in CSO varies depending on the amount of rain. In order to emulate this in an experimentally practical way, we defined three qualities of simulated CSO water that were used for laboratory experiments. Laboratory simulated CSOs were made by preparing dilutions of freshly collected raw wastewater into demineralized water, in order to match the matrix content of the overflow at different times in the overflow event. CSO simulated with $40 \%$ wastewater represents the first flush of an overflow event, CSO simulated with $15 \%$ wastewater represents the typical overflow, and CSO simulated with 5\% wastewater represents the extended overflow event with a higher dilution (Passerat et al., 2011). Selection of the raw wastewater concentrations used to simulated CSO water were based on studies of ammonia concentrations in a time series of different CSO events from different locations in Denmark (See supplementary information Table S1-S4). Chemical oxygen demand (COD), turbidity, conductivity, and alkalinity matched the design data where these parameters were determined.

Unless otherwise stated, for all experiments reported, the raw wastewater was collected from Lundtofte WWTP, Denmark, and stored at $4^{\circ} \mathrm{C}$ until experiments were performed. Lundtofte WWTP has a catchment area of a $32 \mathrm{~km} 2$ and treats domestic wastewater for approximately 130,000 p.e. The diluted raw wastewater with demineralized water was used for chemical and microbiological analyses before and after disinfection. At minimum, ammonia was measured in each collected sample of wastewater, but in most cases, COD, turbidity, conductivity, and alkalinity were all measured in both the wastewater and the simulated CSOs, in order to verify the dilutions and variability in the wastewater.

\subsection{Chemical analysis}

$\mathrm{COD}, \mathrm{pH}, \mathrm{NH}_{4}-\mathrm{N}$, alkalinity, turbidity and conductivity were determined according to standard methods (APHA, 2012) and using SOPs and control methods (x-charts etc.) of the Laboratory at the Department of Environmental Engineering, Technical University of Denmark, Denmark.

The concentration of PAA and PFA were quantified by the selective oxidation reaction for organic peroxides with the colorless ABTS, to form a green product, which was quantified by absorption at $405 \mathrm{~nm}$. In order to minimize the cross reaction with $\mathrm{H}_{2} \mathrm{O}_{2}$, the analytical reagents were modified by omitting iodide and optimizing the reaction time, as in the method described by (Pinkernell et al., 1997). Sample analysis consisted of mixing $350 \mu \mathrm{L} 1.0 \mathrm{M}$ acetic acid (adjusted to $\mathrm{pH} 3.50$ with $\mathrm{NaOH}$ ) with $350 \mu \mathrm{L} 1.0 \mathrm{~g} \cdot \mathrm{L}^{-1}$ ABTS, and then adding $350 \mu \mathrm{L}$ of sample. The color was allowed to 
develop for $10 \mathrm{~min}$ in the case of PAA and $20 \mathrm{~min}$ in the case of PFA, before quantification in a 1.0 cm polypropylene cuvette, using a Varian Cary $200 \mathrm{UV}-$ Vis photometer. Samples were quantified by using the extinction coefficient of the oxidized ABTS, recalculated to 8.55 and $6.74 \mathrm{mg} \cdot \mathrm{L}^{-1} \cdot \mathrm{Abs}^{-}$ 1 , for PAA and PFA, respectively. Originally, the coefficients were calculated from results by (Pinkernell et al., 1997), and controlled by comparison with analysis based on titration.

\subsection{Microbiological analysis}

Samples were processed within $2 \mathrm{~h}$ after collection. Any residues of disinfectant were neutralized by adding sodium thiosulphate to yield $100 \mathrm{mg} \cdot \mathrm{L}^{-1}$, followed by catalase to yield $50 \mathrm{mg} \cdot \mathrm{L}^{-1}$ (100,000-250,000 units/L) (Wagner et al., 2002).

E. coli was enumerated by the most probable number (MPN) method (APHA, 2012; ISO, 2012) using 97-Well Quanti-Tray and Colilert-18 reagent. To detect E. coli, Colilert-18 reagent was mixed with $100 \mathrm{ml}$ sample, then poured and sealed into a 97-well Quanti-Tray. After incubation at 35 \pm 0.5 ${ }^{\circ} \mathrm{C}$ for $18 \mathrm{~h}$, yellow wells with fluorescent in a $365 \mathrm{~nm}$ UV light were counted as positive for $E$. coli. The number of positive wells was converted to MPN according the MPN table provided by IDEXX (IDEXX laboratories, Maine, United States), results were expressed as MPN $(100 \mathrm{ml})^{-1}$.

Enterococcus was also enumerated using the MPN method with a 97-Well Quanti-Tray and Enterolert reagent (APHA, 2012). To detect Enterococcus, Enterolert reagent was mixed with 100 $\mathrm{mL}$ of sample, then poured and sealed into a 97-well Quanti-Tray. After incubation at $41 \pm 0.5^{\circ} \mathrm{C}$ for $24 \mathrm{~h}$, fluorescent wells under illumination by a UV lamp at $365 \mathrm{~nm}$ were counted as positive for Enterococcus. The number of positive wells was converted to MPN by referring MPN table provided by IDEXX and results were expressed as MPN $(100 \mathrm{ml})^{-1}$.

The toxicity of the disinfectant used was evaluated with the bacterial bioluminescence assay based on the ISO protocol (ISO, 2007), using the luminometer Luminoskan TL Plus (Thermo lab system). Analysis was carried out with all dilutions and reagents tempered at $15^{\circ} \mathrm{C}$, using the luminescent bacteria Vibrio fischeri. The concentration of toxicants (disinfectants) in the test causing 50\% inhibition of bioluminescence, after exposure for $15 \mathrm{~min}$, was designated as the $\mathrm{EC}_{50}$ value.

\subsection{Experiment performed}

The effects of different initial concentrations of PFA and PAA $\left(1-30 \mathrm{mg} \cdot \mathrm{L}^{-1}\right)$ and reaction time $(5$ $-360 \mathrm{~min}$ ) on the three types of simulated CSO water were studied in CSO based on wastewater collected on 9 days during the experimental period. Furthermore, time profiles of different concentrations of disinfectants $\left(1-30 \mathrm{mg} \cdot \mathrm{L}^{-1}\right)$ in the three types of simulated CSO water were studied.

A toxicity experiments were performed using simulated CSO based on wastewater collected from a sewage pipe at the CSO structure in Tune (Denmark). This CSO structure consists of a series of retention basins from which the last in the series overflow into Tune stream. It is considered to disinfect this overflow by adding a disinfectant to the second basin in the series of basins which will result in a median retention time of $16 \mathrm{~h}$. The 3 types of Simulated CSO were disinfected with 10 ppm PAA or 4 ppm PFA and concentration profiles were recorded as well as the Microtox after 16 h.

Based on results from the batch scale disinfection experiment on simulated CSO water, a full-scale disinfection is being considered to be performed at a CSO structure using the commercial DesinFix system (Kemira AB, Helsingborg, Sweden). Skovshoved pumping station relays domestic wastewater from a part of Gentofte municipality (North of Copenhagen) to the Lynetten WWTP in Copenhagen. When the pipe and pumping capacity is exceeded during rain events, this installation bypasses CSO via a $1.6 \mathrm{~km}$ long outfall pipe into Øresund (sea near Copenhagen). The hydraulic retention time in the pipe is a minimum of $24 \mathrm{~min}$ before discharge. In the intended experimental run, PFA could be dosed to the inlet of the outfall pipe. Authentic CSO was collected in fractions by an auto sampler, which was set to collect a $1 \mathrm{~L}$ sample every $20 \mathrm{~min}$ during a rain event, which 
occurred on 9 August 2013.

\subsection{RESULTS AND DISCUSSION}

\subsection{Simulated CSO characterization}

Variation in the simulated CSO, stemming from variability in the raw wastewater collected, was checked by chemical analysis of raw- and wastewater, diluted with demineralized water. COD, alkalinity, $\mathrm{pH}$, conductivity, and $\mathrm{NH}_{4}-\mathrm{N}$ were measured from raw and diluted wastewater to ensure that the measured values complied with the variation in dilution. Among other values from the chemical analysis, $\mathrm{NH}_{4}-\mathrm{N}$ was found to be more proportional in dilution from raw wastewater. $\mathrm{NH}_{4}-\mathrm{N}$ in raw wastewater was $35.5 \mathrm{mg} \cdot \mathrm{L}^{-1}$, and when diluted to 5,15 , and $40 \%, \mathrm{NH}_{4}-\mathrm{N}$ was 1.75 , 4.9 , and $13.5 \mathrm{mg} \cdot \mathrm{L}^{-1}$, respectively. Whereas, the COD of raw wastewater was $306 \mathrm{mg} \cdot \mathrm{L}^{-1}$, but when diluted to 5,15 , and $40 \%$, the COD was $8.03,26.45$, and $127 \mathrm{mg} \cdot \mathrm{L}^{-1}$, respectively. When simulated CSO was produced from different portions of freshly collected raw wastewater, the amount of raw wastewater used was normalized by $\mathrm{NH}_{4}-\mathrm{N}$, since other parameters (i.e. COD, Alkalinity, and turbidity) varied only marginally from day-to-day in simulated CSO.

\subsection{Concentration measurements}

When the analytical method for PAA analysis in river and drinking water; based on oxidation of iodide and ABTS as described by (Pinkernell et al., 1997), was used on CSO water, control experiments were greatly biased due to the iodide reacting with $\mathrm{H}_{2} \mathrm{O}_{2}$. A similar problem was observed with the method previously described for PAA in biologically treated wastewater; using iodide and $N, N$-diethyl-p-phenylenediamine (DPD) buffered at higher than usual $\mathrm{pH}$ applied in analytical procedures for oxidants in water based on DPD (Hey et al., 2012). Presumably, one or more components in the raw wastewater catalyze the oxidation of iodide by hydrogen peroxide. To avoid interference with iodide, the method was modified by omitting iodide, in order to utilize the high selectivity of organic peroxides in directly oxidizing ABTS, without the iodide/tri-iodide intermediate. This modified analytical method yielded stable results and a large linear range for quantification. The same modified method was also found to be suitable for PFA analysis, but optimizing the signal-to-noise ratio of the analytical signal suggested that a different reaction time was optimal. The analysis of PFA by DPD was attempted according to the method described by (Hey et al., 2012) for PAA; however, in both simulated CSO and tap water, a fast bleaching of the DPD color was observed, which prevented quantitative measurements. It is concluded that PFA oxidizes the DPD reagent directly or in a second reaction, to a colorless product. However, in principle, when oxidation by halogens takes place, the oxidized DPD will exhibit a pink color.

\subsection{Concentration profiles}

The profiles of consumption of the two organic peroxides in simulated extended overflow water (5\% wastewater) (Figure 1A/B and Figure S2) revealed that PAA disappears slower than PFA. When $6.32 \mathrm{mg} \cdot \mathrm{L}^{-1}$ PFA was added, roughly $36 \%$ of PFA was degraded after $120 \mathrm{~min}$ and $77 \%$ of PFA had disappeared after $300 \mathrm{~min}$; whereas after addition of $7.81 \mathrm{mg} \cdot \mathrm{L}^{-1} \mathrm{PAA}$, only $22 \%$ disappeared after $300 \mathrm{~min}$. In the experiment where $1.55 \mathrm{mg} \cdot \mathrm{L}^{-1} \mathrm{PFA}$ was added to simulated extended overflow water (5\% wastewater), roughly $97 \%$ disappeared after $120 \mathrm{~min}$ (Figure $1 \mathrm{~B}$ ). Similarly, $1.19 \mathrm{mg} \cdot \mathrm{L}^{-1}$ PAA was decomposed by only $2 \%$ in simulated extended overflow water (5\% wastewater) after 180 $\min$.

A small initial consumption of PAA and PFA was observed for all three types of CSO water. Initial consumption increased when the matrix density increased. When $8.46 \mathrm{mg} \cdot \mathrm{L}^{-1} \mathrm{PAA}$ was added in simulated typical overflow water (15\% wastewater), $11 \%$ of PAA disappeared within 1 min, and when $1.19 \mathrm{mg} \cdot \mathrm{L}^{-1}$ PAA was added in the simulated $\mathrm{CSO}$ with the same water quality, approximately $13 \%$ was degraded within $1 \mathrm{~min}$ after addition. Similarly when $8.87 \mathrm{mg} \cdot \mathrm{L}^{-1} \mathrm{PAA}$ was added in simulated typical overflow water (15\% wastewater), approximately $11 \%$ was degraded after $1 \mathrm{~min}$, but $23 \%$ was degraded within $1 \mathrm{~min}$ of addition in first flush water (40\% 
wastewater) treated with the same concentration of PAA. A similar effect on initial consumption of PFA in CSO simulated with a different concentration of wastewater was observed. When 6.32 $\mathrm{mg} \cdot \mathrm{L}^{-1}$ PFA was added in a simulated typical overflow water (15\% wastewater), $10 \%$ was consumed within $1 \mathrm{~min}$, consequently 16 and 20\% degradations were observed when 2.78 and 1.59 $\mathrm{mg} \cdot \mathrm{L}^{-1}$ PFA was added, respectively, in simulated typical overflow water ( $15 \%$ wastewater). This indicates that initial consumption increases when low concentrations of PFA are used.

Initial consumptions were increased from approximately $5 \%$ in simulated extended overflow water ( $5 \%$ wastewater) to $22 \%$ in first flush water ( $40 \%$ wastewater), when $3.37 \mathrm{mg} \cdot \mathrm{L}^{-1} \mathrm{PFA}$ was added within 1 min.

PAA degradation was stable in both acidic and neutral $\mathrm{pH}$ conditions which is shown in Figure 1A. PFA degradation was stable in the acidic $\mathrm{pH}$ condition, whereas degradation of PFA increased markedly at $\mathrm{pH} 7$ and above (Figure 1B).

The consumption of PAA in a more concentrated CSO, such as the first flush water $(40 \%$ wastewater, Figure 1C) is slightly faster compared to the consumption in extended overflow water ( $5 \%$ wastewater). However, the consumption rate of PAA is very slow compared to the consumption of PFA, and complete consumption of the $3.37 \mathrm{mg} \cdot \mathrm{L}^{-1} \mathrm{PFA}$ was achieved after 120 min in all of the three simulated CSO waters, irrespective of the matrix density (Figure 1D).

The profiles of consumption of the two organic peroxides in sea water (Figure $1 \mathrm{E} / \mathrm{F}$ ) showed that PFA degrades faster than PAA. The degradation of PAA was faster in sea water compared to simulated CSO water but the degradation of PFA in sea water was similar to simulated CSO water. When $2.2 \mathrm{mg} \cdot \mathrm{L}^{-1}$ of PAA was added to sea water, $91 \%$ was degraded after $240 \mathrm{~min}$. Similarly, when $1.5 \mathrm{mg} \cdot \mathrm{L}^{-1}$ of PFA was added to sea water, $94 \%$ was degraded after $150 \mathrm{~min}$.
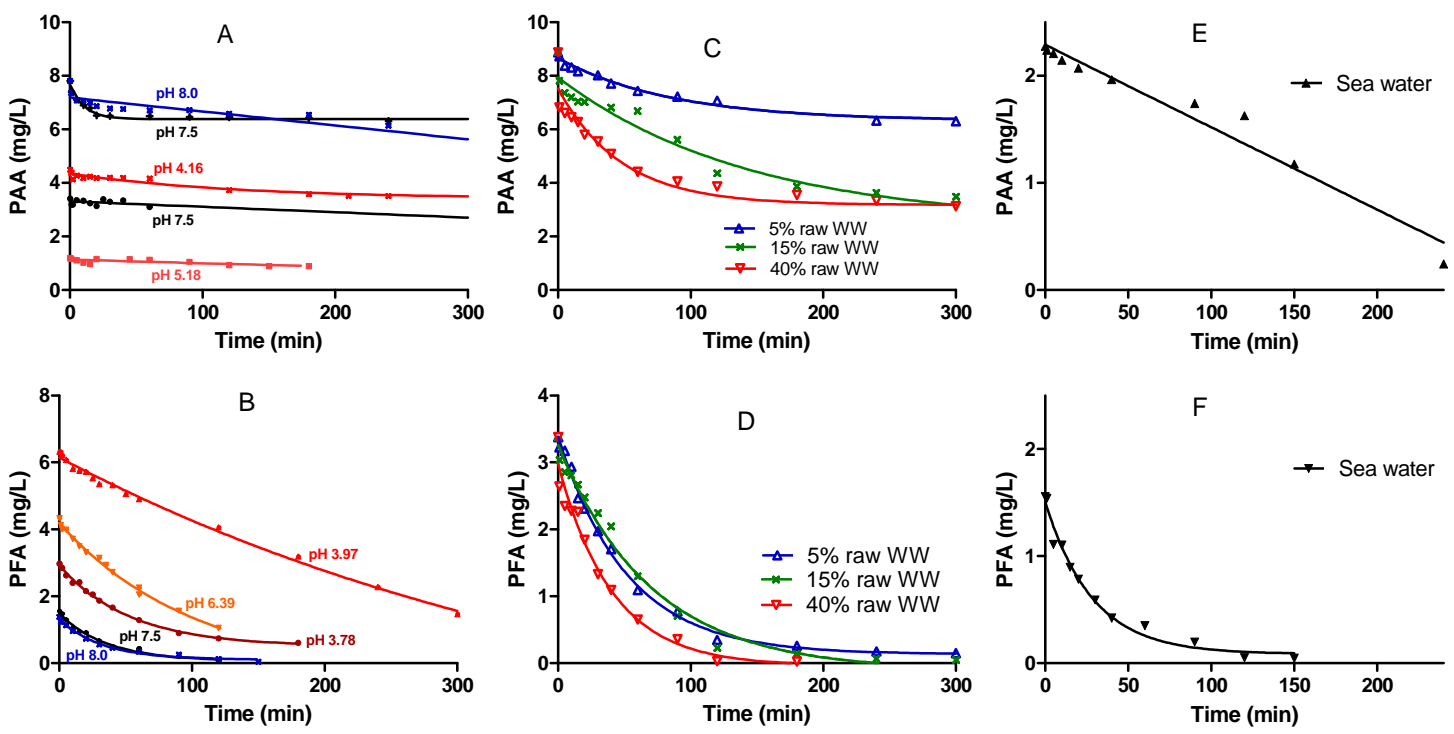

Figure 1: Concentration profiles of PAA (A) and PFA (B) at different $\mathrm{pH}$ in simulated extended overflow water (5\% wastewater). Graph $\mathrm{C}$ and D illustrate the matrix influence on concentration profile of organic peroxides. Graph $\mathrm{E}$ and $\mathrm{F}$ shows the concentration profiles of PAA and PFA in seawater collected at near the point the sea outfall pipe enters the Øresund.

\subsection{Disinfection efficiency}

Results plotted in figure 2A illustrate disinfection with different initial concentrations of PAA, ranging from 2.5 to $30 \mathrm{mg} \cdot \mathrm{L}^{-1}$, in simulated extended overflow water ( $5 \%$ wastewater) with $10 \mathrm{~min}$ contact time. Disinfection efficiency of PAA for E. coli was in range of 3.4-5.6 log units. In all of the experiments with E. coli, the final concentration was below the detection level, whereas the disinfection efficiency against Enterococcus was weak; the removal never exceeding $2 \operatorname{logs}$. PFA removed 1.8 to $>5.7 \operatorname{logs}$ of $E$. coli when 1 to $8 \mathrm{mg} \cdot \mathrm{L}^{-1}$ of PFA were applied (Figure $2 \mathrm{~B}$ ). Disinfection using PFA always achieved a higher removal of indicator organisms with lower doses compared to PAA. The results suggest that in all cases Enterococcus was more difficult to remove 
with respect to E. coli. Therefore, disinfection of Enterococcus is considered in the following experiments, as it is certain that dimensioning of the disinfection systems, with the aim to maintain bathing water quality (Directive 2006/7/EC, 2006), has to be based only on Enterococcus.

The matrix density, and thus the number of indicator organisms present in CSO water, changes over time in a CSO event. To investigate the effect of matrix density, experiments were carried out in the three types of simulated CSO water (Figure 2C/D) as rationalized in sections 2.2 and 3.1. Applying as high as $30 \mathrm{mg} \cdot \mathrm{L}^{-1}$ PAA only removed $2 \operatorname{logs}$ of Enterococcus from simulated typical overflow water (15\% wastewater) and first flush water (40\% wastewater). Except for the high PAA dose of $30 \mathrm{mg} \cdot \mathrm{L}^{-1}$, the removal of Enterococcus failed to exceed $2 \operatorname{logs}$. Removal of Enterococcus was always more than $3 \operatorname{logs}$ when 4 to $12 \mathrm{mg} \cdot \mathrm{L}^{-1} \mathrm{PFA}$ was applied with $10 \mathrm{~min}$ contact time. Removal of Enterococcus was less than $1 \log$ in the experiment where simulated extended overflow water (5\% wastewater) was disinfected with $1 \mathrm{mg} \cdot \mathrm{L}^{-1}$ PFA with $10 \mathrm{~min}$ contact time; the same $\log$ removal of Enterococcus was observed in the experiment where simulated first flush water (40\% wastewater) was disinfected with $4 \mathrm{mg} \cdot \mathrm{L}^{-1} \mathrm{PFA}$. Thus, the disinfection efficientness of $1 \mathrm{mg} \cdot \mathrm{L}^{-1}$ PFA was not sufficient to remove Enterococcus from simulated extended overflow water $(5 \%$ wastewater). Disinfection efficiency of both PAA and PFA decreased slightly with an increase in matrix concentration in CSO.
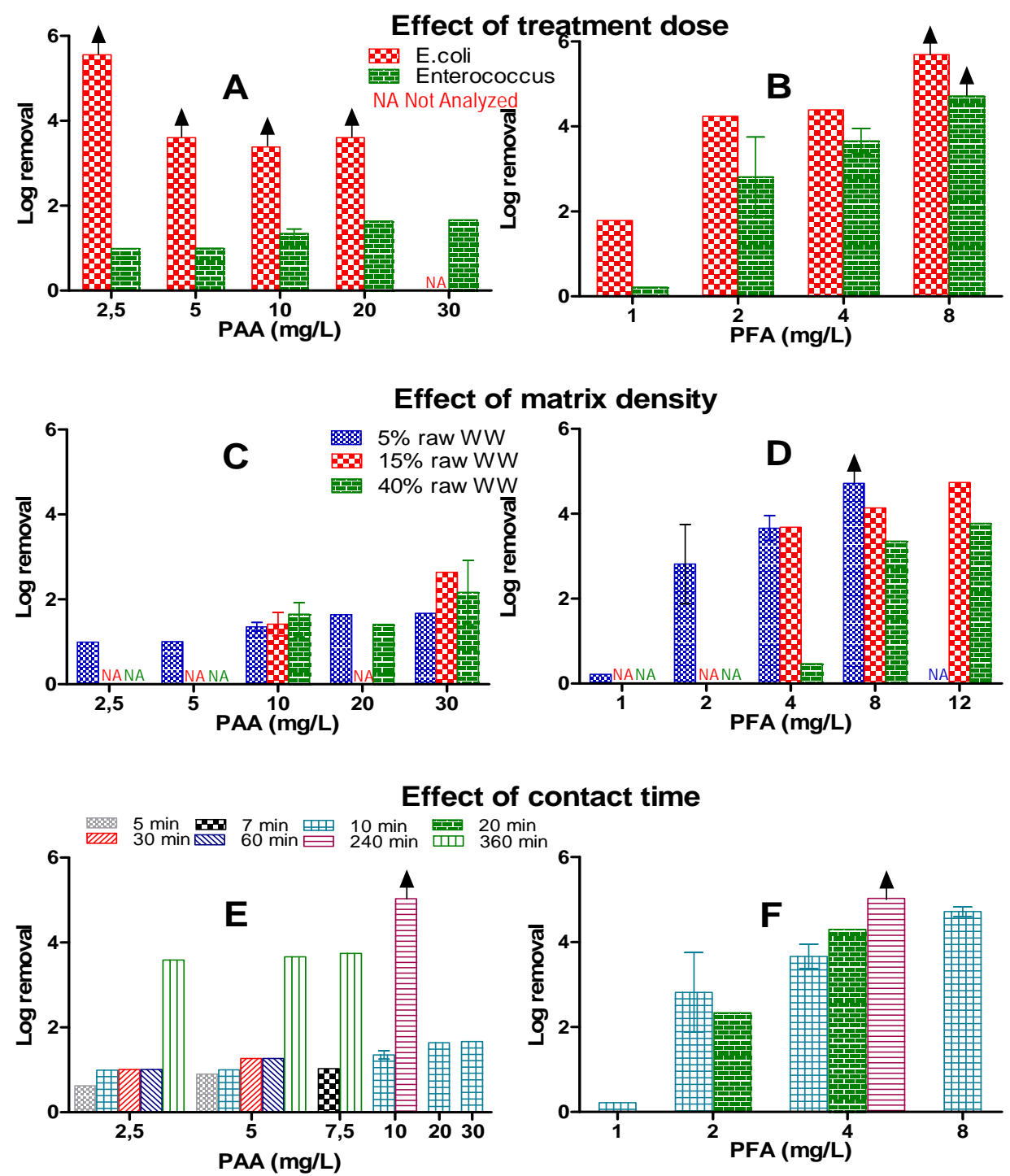

Figure 2: Disinfection efficiency of PAA and PFA in different simulated CSOs. Graphs A/B plot disinfection efficiency of different initial concentrations of organic peroxides on different indicator organisms. Simulated extended overflow water (5\% wastewater) and the contact time is $10 \mathrm{~min}$. Graphs $\mathrm{C} / \mathrm{D}$ plot the matrix influence on disinfection efficiency of organic peroxides with 10 min contact time for Enterococcus illustrated by three simulated CSO qualities. Graphs E/F plot the effect of initial concentration of organic 
peroxide and contact time on Enterococcus in simulated extended overflow water (5\% wastewater). The T-bars indicate the range of the mean of results when the treatment was repeated on different days (interday variability), and ' $\boldsymbol{\Delta}$ ',(arrow) indicates that the log removal is greater than the value shown by the bar as the indicator organism MPN was below the detection limit after the treatment.

To investigate the effect of contact time on the disinfection efficiency of the two organic peroxides, experiments were carried out with 5 to 360 min of contact time. Results are illustrated in Figure $2 \mathrm{E} / \mathrm{F}$. Results from applying a low PAA dose of $2.5 \mathrm{mg} \cdot \mathrm{L}^{-1}$ with $360 \mathrm{~min}$ of contact time removed more than $3 \operatorname{logs}$ of Enterococcus, compared to $1.5 \mathrm{logs}$ removal at $10 \mathrm{~min}$ of contact time. Similarly, $10 \mathrm{mg} \cdot \mathrm{L}^{-1}$ PAA with $240 \mathrm{~min}$ of contact time removed Enterococcus by more than $4 \operatorname{logs}$ compared to $1.5 \operatorname{logs}$ at 10 min contact time. This means that PAA is only suited for CSO structures which have a long retention time. The disinfection efficiency of PFA also increased with increased contact time, but on a much shorter time scale. For example, $4 \mathrm{mg} \cdot \mathrm{L}^{-1} \mathrm{PFA}$ resulted in $3.8 \operatorname{logs}$ removal at $10 \mathrm{~min}$, and the removal increased to $>5 \operatorname{logs}$ at $240 \mathrm{~min}$ of contact time. Applying 2 $\mathrm{mg} \cdot \mathrm{L}^{-1}$ PFA with 10 min contact time already reduced the number of Enterococcus by roughly 3 logs, to less than the EU bathing water directive limit of 200 organisms per $100 \mathrm{~mL}$. This makes PFA suitable for a treatment facility that has a short retention time.

\subsection{Treatment perspectives}

From the experiments performed on the laboratory simulated CSO water, it was found that the degradation of PAA was slower than PFA in all types of CSO. Furthermore, decomposition of PFA was affected more by a fluctuation in $\mathrm{pH}$ and matrix density with respect to PAA. Disinfection using PAA was not efficient with a short contact time, but with a long contact time, indicator organisms were efficiently removed. Additionally, PAA was considerably less efficient for Enterococcus than for E. coli. Disinfection efficiency of PFA with a short contact time and a low initial concentration was much greater. The removal rate of Enterococcus from PFA was almost the same for both coliform and E. coli.

Therefore, it is tentatively concluded from the experiments performed in laboratory scale that PAA can only be used to disinfect CSO water where treatment facilities have a long retention time; whereas PFA can also be used to disinfect CSO water where the overflow structure has a short retention time.

Based upon these findings, we predict, that a disinfection system which can disinfect indicator organisms to below the EU guideline for recreational water, will, for example, need a $360 \mathrm{~min}$ contact time and $5 \mathrm{mg} \cdot \mathrm{L}^{-1}$ of PAA if the first flush water is considered, and a $360 \mathrm{~min}$ contact time and $2 \mathrm{mg} \cdot \mathrm{L}^{-1}$ of PAA for the continued overflow water (CSO water equivalent to a content of $15 \%$ wastewater). If the first flush water is to be disinfected using PFA, a 20 min contact time with 4 $\mathrm{mg} \cdot \mathrm{L}^{-1}$ is needed and $20 \mathrm{~min}$ with $2 \mathrm{mg} \cdot \mathrm{L}^{-1} \mathrm{PFA}$ is needed for continued and extended overflow water in order to maintain that the indicator organisms are within the EU guidelines.

\subsection{Residual toxicity}

Residual toxicity of the three types of simulated CSO water was analyzed 16 hours after treatment with $10 \mathrm{mg} \cdot \mathrm{L}^{-1}$ PAA or $4 \mathrm{mg} \cdot \mathrm{L}^{-1}$ PFA (Figure 3). Controls in all experiments (Figure $3 \mathrm{~A} / \mathrm{B} / \mathrm{C}$ ) demonstrated that all the three CSO waters were slightly toxic when not diluted; however, at dilutions of $50 \%$ or higher, the toxicity was minimal. The simulated extended overflow water $(5 \%$ wastewater), treated with $4 \mathrm{mg} \cdot \mathrm{L}^{-1} \mathrm{PFA}$, shows slight toxicity in relation to the untreated CSO, but no toxicity was observed in the sample with $50 \%$ dilution (Figure 3A). Simulated extended overflow water ( $5 \%$ wastewater) treated with $10 \mathrm{mg} \cdot \mathrm{L}^{-1}$ PAA was very toxic to the Microtox ${ }^{\circledR}$ bacteria, Vibrio fischeri. The toxicity of this sample was reduced with dilution, and when it was diluted to $6 \%$, the inhibition decreased to $80 \%$ of the response; whereas no toxicity was observed when it was diluted further to $3 \%$. This result can be justified by slow degradation on PAA, especially in diluted CSO (Figure 1C).Consequently, residual PAA remains in this treated water at the time of the toxicity measurement. Slight toxicity was observed in the simulated typical overflow water (15\% wastewater) and the first flush water ( $40 \%$ wastewater) treated with PAA and PFA, but 
no toxicity was observed when $\mathrm{CSO}$ water was diluted to $25 \%$ (Figure 3B/C). In parallel, the toxicity of PAA, PFA and $\mathrm{H}_{2} \mathrm{O}_{2}$ was determined in terms of $\mathrm{EC}_{10}$ and $\mathrm{EC}_{50}$. $\mathrm{EC}_{10}$ of PAA, PFA and $\mathrm{H}_{2} \mathrm{O}_{2}$ was 78,341 , and $11,000 \mu \mathrm{g} \cdot \mathrm{L}^{-1}$, respectively and $\mathrm{EC}_{50}$ of PAA, PFA and $\mathrm{H}_{2} \mathrm{O}_{2}$ was 109,376 , and $12,000 \mu \mathrm{g} \cdot \mathrm{L}^{-1}$, respectively (See supplementary information Table S6).
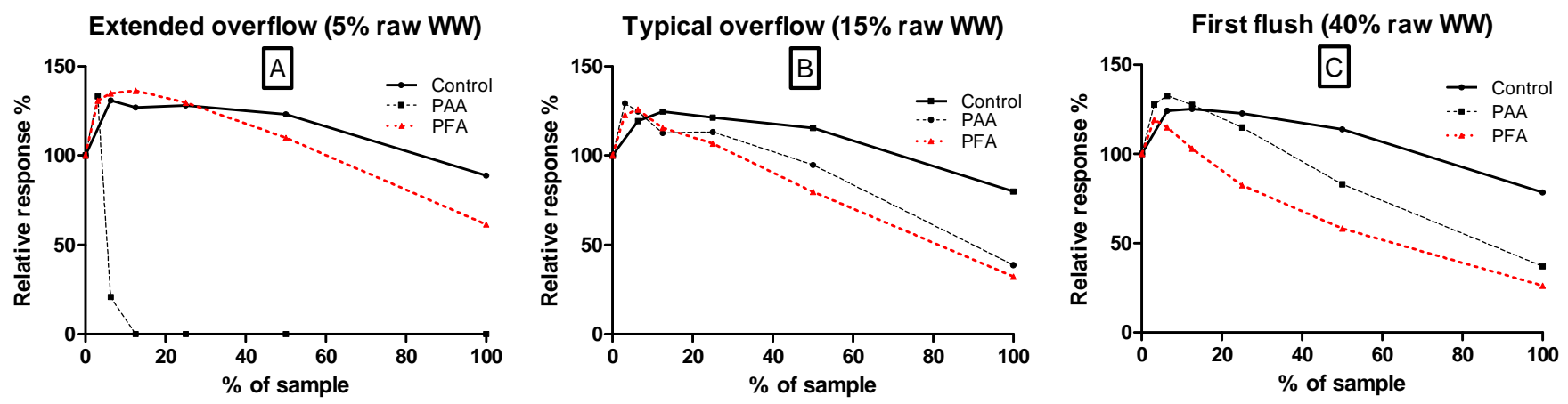

Figure 3: Residual toxicity in three simulated CSOs, $16 \mathrm{~h}$ after dosing $10 \mathrm{mg} \cdot \mathrm{L}^{-1} \mathrm{PAA}$ or $4 \mathrm{mg} \cdot \mathrm{L}^{-1} \mathrm{PFA}$.

\subsection{Pre- field design evaluation experiment}

To design a full scale disinfection system and to confirm our laboratory results, we performed a prefield experiment using CSO water collected from Skovshoved pumping station. Eight one-liter bottles were filled ( 1 sample every $4 \mathrm{~min}$ and 5 samples per bottle) with different quality of CSO throughout the 2.7 hours that the overflow event lasted. Conductivity, $\mathrm{pH}, \mathrm{NH}_{4}-\mathrm{N}$, alkalinity, and turbidity were measured in the eight bottles to establish a profile of the overflow event (See supplementary information Table S1). For the experiments, we mixed the first three sample bottles with CSO fractions to make CSO with an ammonium concentration similar to first flush water (40\% wastewater), the remaining five sample bottles with CSO fractions were mixed to make a CSO similar to typical overflow water $(15 \%$ wastewater based on ammonium concentration) (See supplementary information Table S1).

PFA was selected to disinfect CSO, as it had shown efficient disinfection of simulated CSO in batch-scale tests with a short contact time. Typical overflow water (ammonia concentration was equivalent to $15 \%$ wastewater) was disinfected with 2 and $4 \mathrm{mg} \cdot \mathrm{L}^{-1} \mathrm{PFA}$, and the first flush water (ammonia concentration was equivalent to $40 \%$ wastewater) was disinfected with 4 and $8 \mathrm{mg} \cdot \mathrm{L}^{-1}$ PFA. After $20 \mathrm{~min}$ of reaction time, which is almost equal to the 24 min retention time that would occur in the outfall pipe at maximal flow, microbiological analysis was performed. The residual PFA and hydrogen peroxide was quenched by adding $100 \mathrm{mg} \cdot \mathrm{L}^{-1}$ sodium thiosulphate, followed by $50 \mathrm{mg} \cdot \mathrm{L}^{-1}$ catalase. Concentration profiles of disinfectant on CSO were measured for 2 hours. It was observed that the experiment with lower PFA concentration degraded completely after $120 \mathrm{~min}$ (Figure 4A), and, 38\% of the PFA was degraded within 1 min. The experiment with higher PFA concentration degraded faster in the first flush water ( $40 \%$ wastewater, Figure $4 \mathrm{~B})$, and, $62 \%$ of the PFA was degraded within 1 min.
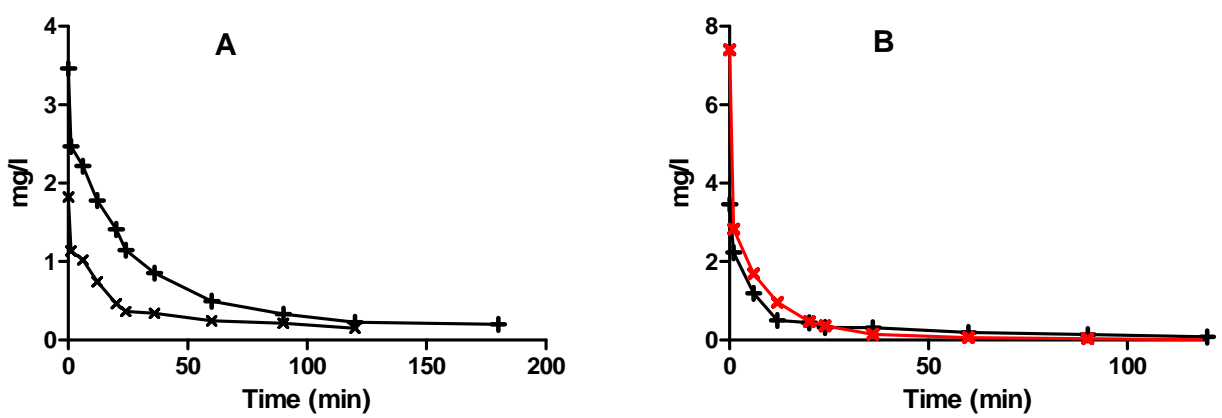

Figure 4: Concentration profile of PFA in typical overflow water (15\% wastewater) (A) and concentration profile of PFA in first 
As expected, PFA showed an efficient removal of E. coli and Enterococcus (Table 1). E. coli and In typical overflow water (15\% wastewater) E. coli and Enterococcus concentrations were below the bathing water directive when disinfected with $2 \mathrm{mg} \cdot \mathrm{L}^{-1}$; whereas, Enterococcus concentration was higher than the bathing water directive in the first flush water (40\% wastewater) disinfected with 4 $\mathrm{mg} \cdot \mathrm{L}^{-1}$. Increasing the PFA concentration to $8 \mathrm{mg} \cdot \mathrm{L}^{-1}$ did not improve the disinfection efficiency (Table 1).

The CSO water from the Skovshoved pumping station is discharged into the Øresund. CSO water is diluted a minimum of 75 times within a $50 \mathrm{~m}$ radius around the discharge point, thus, it can be assumed that the number of indicator organisms will also be diluted by the same factor.

Table 1: Concentrations and removal efficiency for indicator organisms from treating CSO water fractions with PFA. 95\% Confidence intervals indicated in parenthesis (intraday variation).

Concentrations after disinfection

Log removal

\begin{tabular}{ccccccc}
\hline & PFA(mg/L) & Time(min) & $\begin{array}{c}\text { E.coli } \\
(\text { MPN/100mL) }\end{array}$ & $\begin{array}{c}\text { Enterococcus } \\
(\text { MPN/100mL) }\end{array}$ & E.coli & Enterococcus \\
\hline $\begin{array}{c}\text { Typical } \\
\text { CSO } \\
(\mathbf{1 5 \%} \text { WW) }\end{array}$ & $\mathbf{2}$ & $\mathbf{2 0}$ & $36(20-71)$ & $195(133-274)$ & $\begin{array}{c}4.67(4.56- \\
4.72)\end{array}$ & $2.74(2.70-2.78)$ \\
\hline $\begin{array}{l}\text { First flush } \\
\text { CSO (40\% } \\
\text { WW) }\end{array}$ & $\mathbf{4}$ & $\mathbf{2 0}$ & $4(1-9)$ & $28(17-60)$ & $\begin{array}{c}5.61(5.46- \\
5.94)\end{array}$ & $3.58(3.44-3.60)$ \\
\hline
\end{tabular}

\subsection{CONCLUSION}

- This study suggests that PAA can be used to treat CSO water when the overflow occurs through structures enabling a very long retention time; in the order of several hours. However, the decomposition was also found to be slow, compared to typical contact times in CSO structures, as well as being dependent on the matrix density.

- PFA is a more efficient disinfectant at low doses with short contact times. PFA degradation was nearly independent of matrix density in $\mathrm{CSO}$, thus appearing to be more ideal for most CSO treatments where a short contact time is the norm.

- The residual toxicity of simulated CSO water treated with PFA and PAA was relatively low, and no toxicity was observed when CSO water was diluted to around $50 \%$. The exception was simulated extended overflow water (5\% wastewater) treated with PAA, which showed a high toxicity. This is well explained by a minor residual of PAA that stems from slow degradation in the diluted water.

- We estimate treatment conditions for general CSO water as $2 \mathrm{mg} \cdot \mathrm{L}^{-1}$ PAA with 360 min contact time or $2 \mathrm{mg} \cdot \mathrm{L}^{-1}$ PFA with 20 min contact time.

- CSO water collected from the overflow structures was validated for field experiments and the estimated treatment condition for general CSO water is promising, thus by removing indicator organisms to an appropriate level.

\section{Acknowledgements}

This study presents results from the DesiCSO and FRODO projects. DesiCSO is a project in the Vand-I-byer partnership funded by the Danish council for technology and innovation and FRODO 
is funded by VTU-Fonden. The authors are grateful to Bonnerup Consult, Aarhus Vand and all partners of the DesiCSO and FRODO projects.

\section{References}

Antonelli, M., Rossi, S., Mezzanotte, V., Nurizzo, C., 2006. Secondary effluent disinfection: PAA long term efficiency, Environmental Science and Technology. Affiliation: DIIAR-Environmental Section, Politecnico di Milano, P.zza L. da Vinci 32, 20133 Milano, Italy; Affiliation: DISAT, Università di Milano Bicocca, P.zza della Scienza 1, 20126 Milano, Italy; Correspondence Address: Antonelli, M.; DIIAR-Environm.

APHA, 2012. Standard Methods for the Examination of water and wastewater (22nd Edition). American Public Health Association /American Water Works Association/Water Environment Federation, Washington DC, USA.

Bayo, J., Angosto, J.M., Gómez-López, M.D., 2009. Ecotoxicological screening of reclaimed disinfected wastewater by Vibrio fischeri bioassay after a chlorination-dechlorination process. J. Hazard. Mater. 172, 166-171.

Bellanca, M.A., Bailey, D.S., 1977. Effects of chlorinated effluents on aquatic ecosystem in the lower James River. J. Water Pollut. Control Fed. 49, 639-645.

Directive 2006/7/EC, 2006, 2006. European bathing water directive. Official Journal of the European Union L64, $37-51$.

ECETOC, 1993. European centre for ecotoxicology and toxicology of chemicals, Joint assessment of commodity chemicals no. 22, Hydrogen peroxide CAS No. 7722-84-1 [WWW Document]. URL http://www.ecetoc.org/jaccreports (accessed 5.13.13).

Falsanisi, D., Gehr, R., Santoro, D., Dell'Erba, A., Notarnicola, M., Liberti, L., 2006. Kinetics of PAA demand and its implications on disinfection of wastewaters. Water Qual. Res. J. Canada 41, 398-409.

FRODO, 2014. Forbedret rensning og desinfektion af overløbsvand [WWW Document]. URL http://www.udviklingssamarbejdet.dk/en/projekter/frodo (accessed 2.1.14).

Gehr, R., Chen, D., Moreau, M., 2009. Performic acid (PFA): Tests on an advanced primary effluent show promising disinfection performance. Water Sci. Technol. 59, 89-96.

Glaze, W.H., Henderson IV, J.E., 1975. Formation of organochlorine compounds from the chlorination of a municipal secondary effluent. J. Water Pollut. Control Fed. 47, 2511-2515.

Hey, G., Ledin, A., Jansen, J.L.C., Andersen, H.R., 2012. Removal of pharmaceuticals in biologically treated wastewater by chlorine dioxide or peracetic acid. Environ. Technol. 33, 1041-1047.

Hrudey, S.E., Charrois, W.J., 2012. Disinfection By-products and human health. IWA Publishing, London United Kingdom.

Huang, J., Wang, L., Ren, N., Ma, F., Juli, 1997. Disinfection effect of chlorine dioxide on bacteria in water. Water Res. 31, 607-613.

ISO, 11348-3, 2007. Water quality -- Determination of the inhibitory effect of water samples on the light emission of Vibrio fischeri (Luminescent bacteria test) -- Part 3: Method using freeze-dried bacteria.

ISO, 9308-2, 2012. Water quality -- Enumeration of Escherichia coli and coliform bacteria -- Part 2: Most probable number method.

Kitis, M., 2004. Disinfection of wastewater with peracetic acid: A review. Environ. Int. 30, 47-55.

Koivunen, J., Heinonen-Tanski, H., 2005. Peracetic acid (PAA) disinfection of primary, secondary and tertiary treated municipal wastewaters. Water Res. 39, 4445-4453. 
Liberti, L., Notarnicola, M., 1999. Advanced treatment and disinfection for municipal wastewater reuse in agriculture. Proc. 1998 6th Int. Conf. Adv. Wastewater Treat. Recycl. Reuse 40, 235-245.

Nurizzo, C., Antonelli, M., Profaizer, M., Romele, L., 2005. By-products in surface and reclaimed water disinfected with various agents. Desalination 176, 241-253.

NYC Global Partners, 2011. Best Practice: Redeveloping Industrial Harbor for Public Swimming [WWW Document]. URL http://www.nyc.gov/html/ia/gprb/downloads/pdf/Copenhagen_Harbour Bath.pdf (accessed 5.1.14).

Passerat, J., Ouattara, N.K., Mouchel, J.-M., Rocher, V., Servais, P., 2011. Impact of an intense combined sewer overflow event on the microbiological water quality of the Seine River. Water Res. 45, 893-903.

Pasternak, J.P., Moore, D.R.J., Teed, R.C., 2003. An ecological risk assessment of inorganic chloramines in surface water. Hum. Ecol. Risk Assess. 9, 453-482.

Pinkernell, U., Lüke, H.-J., Karst, U., 1997. Selective photometric determination of peroxycarboxylic acids in the presence of hydrogen peroxide. Analyst 122, 567-571.

Ragazzo, P., Chiucchini, N., Piccolo, V., Ostoich, M., 2013. A new disinfection system for wastewater treatment: Performic acid full-scale trial evaluations. Water Sci. Technol. 67, 2476-2487.

Svecevicius, G., Šyvokiene, J., Stasiunaite, P., Mickeniene, L., 2005. Acute and chronic toxicity of chlorine dioxide (ClO2) and chlorite (ClO2 -) to rainbow trout (Oncorhynchus mykiss). Environ. Sci. Pollut. Res. 12, 302-305.

Tchobanoglous, G., Burton, F.L., Stensel, H.D., 2003. Wastewater Engineering, treatment and Reuse Metcalf \& Eddy Inc. McGraw Hill, New York.

Tree, J.A., Adams, M.R., Lees, D.N., 2003. Chlorination of Indicator Bacteria and Viruses in Primary Sewage Effluent Chlorination of Indicator Bacteria and Viruses in Primary Sewage Effluent 69.

USEPA, 1999. Combined Sewer Overflow Technology Fact Sheet Alternative Disinfection Methods. United States Environmental Protection Agency, Washington DC, USA.

USEPA, 2001. U.S. EPA HPV Chemical Challenge Program Test Plan for the Formates Category [WWW Document]. URL http://www.epa.gov/hpv/pubs/summaries/formates/c13438tp.pdf (accessed 4.24.14).

Wagner, M., Brumelis, D., Gehr, R., 2002. Disinfection of wastewater by hydrogen peroxide or peracetic acid: Development of procedures for measurement of residual disinfectant and application to a physicochemically treated municipal effluent. Water Environ. Res. 74, 33-50.

Watson, K., Shaw, G., Leusch, F.D.L., Knight, N.L., 2012. Chlorine disinfection by-products in wastewater effluent: Bioassay-based assessment of toxicological impact. Water Res. 46, 6069-6083.

White, G.C., 1972. Handbook of chlorination and alternative disinfectants. Van Nostrand Reinhold, New York. 


\title{
Supporting information for: Chemical disinfection of combined sewer overflows waters using performic acid or peracetic acids
}

\author{
Ravi Kumar Chhetri ${ }^{a}$, Dines Thornberg ${ }^{b}$, Jesper Berner ${ }^{c}$, Robin Gramstad ${ }^{d}$, Ulrik Öjstedt ${ }^{d}$, Anitha Kumari \\ Sharma $^{\mathrm{a}}$, Henrik Rasmus Andersen ${ }^{\mathrm{a} 1}$ \\ ${ }^{a}$ Department of Environmental Engineering, Technical University of Denmark, Bygningstorvet, Building 115, 2800 Kgs. Lyngby, \\ Denmark. ${ }^{1}$ Corresponding author: Henrik@ndersen.net. \\ ${ }^{b}$ Udviklingssamarbejdet, c/o, Lynettefællesskabet, Refshalevej 250, 1432 Copenhagen, Denmark. \\ ${ }^{\mathrm{c}}$ Kemira Water Danmark A/S, G-vej 3, 2300 Copenhagen, Denmark \\ ${ }^{\mathrm{d}}$ Kemira Kemi AB, Industrigatan 83, Box 902, 25109 Helsingborg, Sweden.
}

\section{Contents}

Figure S1: Schematic representation of a combined sewer overflows system (left), disinfectant profile in proposed combined sewer overflow through a retention basin or outfall pipe (right)...

Figure S2: Absorbance of $2.5 \mathrm{mg} \cdot \mathrm{L}^{-1}$ peracetic acid (PAA) and hydrogen peroxide $\left(\mathrm{H}_{2} \mathrm{O}_{2}\right)$ without addition of potassium iodide (KI) in simulated CSO (5\% wastewater).....

Figure S3: Absorbance of $2.5 \mathrm{mg} \cdot \mathrm{L}^{-1}$ performic acid (PFA) and hydrogen peroxide $\left(\mathrm{H}_{2} \mathrm{O}_{2}\right)$ without addition of potassium iodide (KI) in simulated CSO (5\% wastewater)

Figure S4: Absorbance of $2.5 \mathrm{mg} \cdot \mathrm{L}^{-1}$ hydrogen peroxide $\left(\mathrm{H}_{2} \mathrm{O}_{2}\right)$ with addition of potassium iodide (KI) in simulated CSO (5\% wastewater)....

Figure S5: Concentration profiles of PFA at different $\mathrm{pH}$ in simulated extended overflow (5\% wastewater), in typical overflow (15\% wastewater) and in first flush (40\% wastewater). 5

Figure S6: Disinfection efficiency of PAA and PFA in different simulated CSOs. 6

Table S1: Chemical analysis of CSO fractions collected at Skovshoved on $9^{\text {th }}$ August 2013....................................... 2

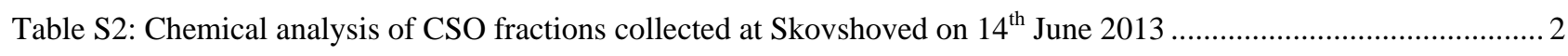

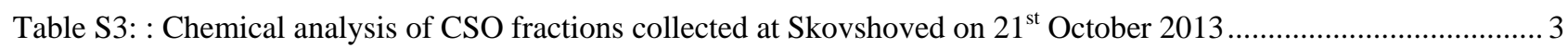

Table S5: Chemical analysis raw wastewater, simulated CSO (5\% WW), simulated CSO (15\% WW) and simulated CSO (40\% WW)

Table S6: $\mathrm{EC}_{10}$ and $\mathrm{EC}_{50}$ values of PAA, PFA and $\mathrm{H}_{2} \mathrm{O}_{2} .95 \%$ confidence intervals are indicated in brackets. 7 

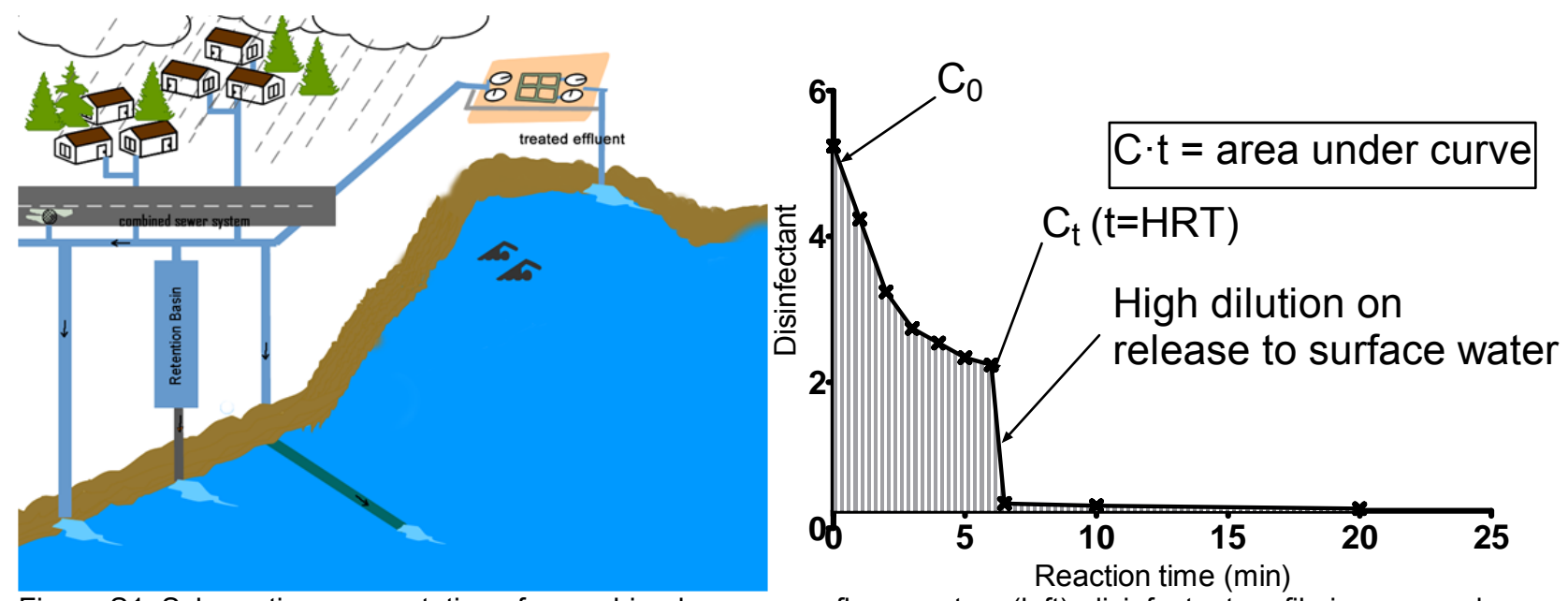

Figure S1: Schematic representation of a combined sewer overflows system (left), disinfectant profile in proposed combined sewer overflow through a retention basin or outfall pipe (right)

\section{Section 1: Chemical analysis of CSO and simulated CSO}

In this section, Table S1, S2, S3 and S4 shows the chemical analysis of combined sewer overflows collected at Skovshoved CSO structure from Denmark. Each CSO fraction was collected every 20 min during overflow event. Table 5 shows the chemical analysis of raw wastewater and diluted wastewater which was used to design different quality of simulated CSO.

Table S1: Chemical analysis of CSO fractions collected at Skovshoved on $9^{\text {th }}$ August 2013.

\begin{tabular}{c|ccccc}
\hline CSO & $p H$ & $\begin{array}{c}\text { Conductivity } \\
(\mathrm{mS} / \mathrm{m})\end{array}$ & $\begin{array}{c}\mathrm{NH}_{4}-\mathrm{N} \\
(\mathrm{mg} / \mathrm{L})\end{array}$ & $\begin{array}{c}\text { Turbidity } \\
(\mathrm{NTU})\end{array}$ & $\begin{array}{c}\text { Alkalinity } \\
(\mathrm{meq} / \mathrm{L})\end{array}$ \\
\hline Fraction 1 & 6.7 & 1132 & 23 & 248 & 5.9 \\
Fraction 2 & 6.7 & 586 & 13 & 187 & 3.2 \\
Fraction 3 & 6.7 & 294 & 6.0 & 236 & 1.8 \\
Fraction 4 & 6.7 & 252 & 4.7 & 218 & 1.3 \\
Fraction 5 & 6.8 & 284 & 5.8 & 197 & 1.6 \\
Fraction 6 & 6.8 & 335 & 4.4 & 184 & 1.6 \\
Fraction 7 & 6.8 & 374 & 4.8 & 192 & 1.6 \\
Fraction 8 & 6.8 & 417 & 7.0 & 179 & 1.7 \\
\hline
\end{tabular}

Table S2: Chemical analysis of CSO fractions collected at Skovshoved on $14^{\text {th }}$ June 2013

\begin{tabular}{c|cccc}
\hline CSO & $p H$ & $\begin{array}{c}\text { Conductivity } \\
(\mathbf{m S} / \mathbf{m})\end{array}$ & $\begin{array}{c}\mathrm{NH}_{4}-\mathrm{N} \\
(\mathrm{mg} / \mathrm{L})\end{array}$ & $\begin{array}{c}\text { Turbidity } \\
(\mathrm{NTU})\end{array}$ \\
\hline Fraction 1 & 7.2 & 1285 & 20.7 & 345,3 \\
Fraction 2 & 7.2 & 1170 & & 323,7 \\
Fraction 3 & 7,2 & $\mathbf{6 8 1}$ & & 343,7 \\
Fraction 4 & 7.2 & 547 & 6.7 & 362,3 \\
Fraction 5 & 7.2 & 420 & & 340,7 \\
Fraction 6 & 7.2 & 306 & & 257,7 \\
Fraction 7 & 7.2 & 274 & 2.9 & 219,7 \\
Fraction 8 & 7.2 & 273 & & 206,3 \\
Fraction 9 & 7.2 & 255 & 2.3 & 144,0 \\
Fraction 10 & 7.2 & 270 & & 196,3 \\
Fraction 11 & 7.2 & 298 & 2.5 & 164,7 \\
Fraction 12 & 7.2 & 334 & & 137,3 \\
Fraction 13 & 7.2 & 391 & 2.8 & 135,0 \\
Fraction 14 & 7.2 & 412 & & 151,0 \\
Fraction 15 & 7.2 & 424 & 4.1 & $\mathbf{1 8 2 , 0}$ \\
Fraction 16 & 7.2 & 433 & 4.3 & 243,7 \\
Fraction 17 & 7.2 & 437 & & 240,7 \\
Fraction 18 & 7.2 & 443 & & 262,0 \\
\hline
\end{tabular}


Table S3: Chemical analysis of CSO fractions collected at Skovshoved on $21^{\text {st }}$ October 2013

\begin{tabular}{c|ccc}
\hline CSO & $p H$ & $\begin{array}{c}\text { Conductivity } \\
(\mathrm{mS} / \mathrm{m})\end{array}$ & $\begin{array}{c}\mathrm{NH}_{4}-\mathrm{N} \\
(\mathrm{mg} / \mathrm{L})\end{array}$ \\
\hline Fraction 1 & 5.7 & 853 & 4,8 \\
Fraction 2 & 5.7 & 1883 & 21,1 \\
Fraction 3 & 5.7 & 1732 & 21,5 \\
Fraction 4 & 5.7 & 751 & 14,9 \\
Fraction 5 & 5.7 & 672 & \\
Fraction 6 & 5.7 & 571 & 10,9 \\
Fraction 7 & 5.7 & 538 & \\
Fraction 8 & 5.7 & 584 & \\
Fraction 9 & 5.7 & 606 & \\
Fraction 10 & 5.7 & 692 & 5,6 \\
\hline
\end{tabular}

Table S4: Chemical analysis of CSO fractions collected at Skovshoved on $28^{\text {th }}$ October 2013

\begin{tabular}{c|ccc}
\hline CSO & $p H$ & $\begin{array}{c}\text { Conductivity } \\
(\mathrm{mS} / \mathrm{m})\end{array}$ & $\begin{array}{c}\mathrm{NH}_{4}-\mathrm{N} \\
(\mathrm{mg} / \mathrm{L})\end{array}$ \\
\hline Fraction 1 & 7.4 & 931 & 13.5 \\
Fraction 2 & 7.3 & 1028 & 16.0 \\
Fraction 3 & 7.4 & 978 & 14.7 \\
Fraction 4 & 7.5 & 850 & 11.9 \\
Fraction 5 & 7.6 & 859 & 12.2 \\
Fraction 6 & 7.6 & 801 & 9.2 \\
Fraction 7 & 7.9 & 742 & 9.1 \\
Fraction 8 & 7.7 & 759 & 11.2 \\
Fraction 9 & 7.7 & 795 & 8.6 \\
Fraction 10 & 7.7 & 751 & 14.2 \\
Fraction 11 & 7.8 & 685 & 11.4 \\
Fraction 12 & 7.7 & 625 & 10.5 \\
Fraction 13 & 7.7 & 608 & 9.4 \\
Fraction 14 & 7.7 & 621 & 6.6 \\
Fraction 15 & 7.7 & 642 & 6.7 \\
Fraction 16 & 7.6 & 666 & 7 \\
\hline
\end{tabular}

Table S5: Chemical analysis raw wastewater, simulated CSO (5\% WW), simulated CSO (15\% WW) and simulated CSO (40\% WW)

\begin{tabular}{c|ccccc}
\hline CSO & $p H$ & $\begin{array}{c}\text { Conductivity } \\
(\mathrm{mS} / \mathrm{m})\end{array}$ & $\begin{array}{c}\mathrm{NH}_{4}-\mathrm{N} \\
(\mathrm{mg} / \mathrm{L})\end{array}$ & $\begin{array}{c}\mathrm{COD} \\
(\mathrm{mg} / \mathrm{L})\end{array}$ & $\begin{array}{c}\text { Alkalinity } \\
(\mathrm{meq} / \mathrm{L})\end{array}$ \\
\hline Raw wastewater & 7.8 & 1880 & 35.5 & 306 & 7.0 \\
Simulated CSO $(5 \% \mathrm{WW})$ & 7.7 & 113 & 1.75 & 40 & 0.52 \\
Simulated CSO $(15 \%$ WW & 7.8 & 327 & 4.9 & 78.8 & 0.60 \\
Simulated CSO $(40 \% \mathrm{WW}$ & 7.8 & 627 & 13.5 & 127 & 3.2 \\
\hline
\end{tabular}




\section{Section 2: Concentration measurement and profiles}

Figure S2 and S3 shows the absorbance of ABTS at $405 \mathrm{~nm}$ in different time when oxidised by $2.5 \mathrm{mg} \cdot \mathrm{L}^{-1}$ peracetic acid (PAA), performic acid (PFA) and hydrogen peroxide in simulated CSO (5\% wastewater) without addition of potassium iodide (KI). Figure S4 shows the absorbance of ABTS at $405 \mathrm{~nm}$ in different time when oxidised by 2.5 $\mathrm{mg} \cdot \mathrm{L}^{-1}$ hydrogen peroxide in simulated CSO (5\% wastewater) with addition of potassium iodide (KI). Figure S5 shows the concentration profiles of PFA and PAA at different $\mathrm{pH}$ in simulated extended overflow (5\% wastewater), in typical overflow (15\% wastewater) and in first flush ( $40 \%$ wastewater). Concentration profiles with open symbols were conducted in wastewater collected from Lundtofte wastewater treatment plant and concentration profiles with closed symbols were conducted in wastewater collected from Greve wastewater treatment

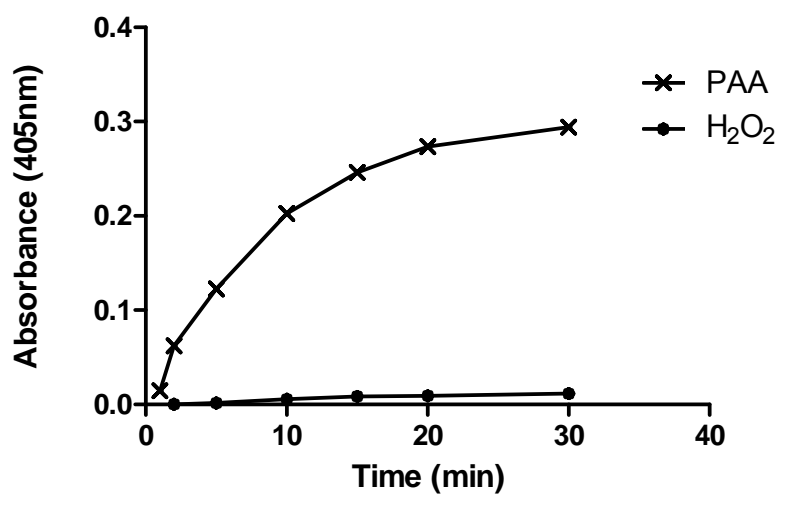

Figure S2: Absorbance of ABTS at $405 \mathrm{~nm}$ when oxidised by $2.5 \mathrm{mg} \cdot \mathrm{L}^{-1}$ peracetic acid (PAA) and hydrogen peroxide $\left(\mathrm{H}_{2} \mathrm{O}_{2}\right)$ without addition of potassium iodide $(\mathrm{KI})$ in simulated $\mathrm{CSO}(5 \%$ wastewater $)$

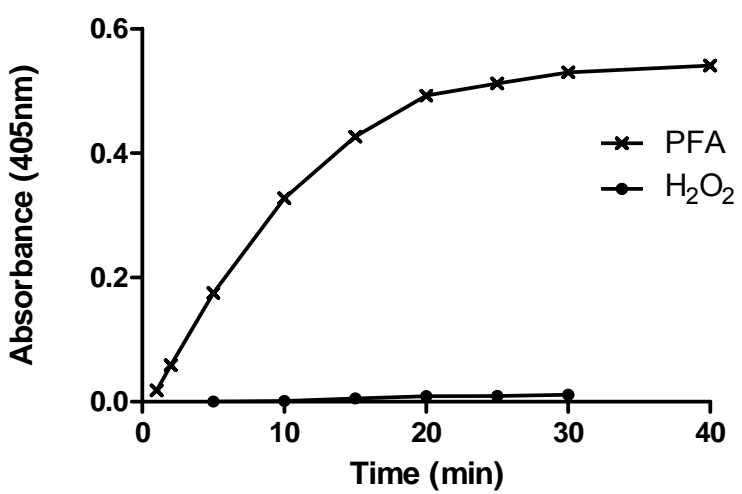

Figure S3: Absorbance of ABTS at $405 \mathrm{~nm}$ when oxidised by $2.5 \mathrm{mg} \cdot \mathrm{L}^{-1}$ performic acid (PFA) and hydrogen peroxide $\left(\mathrm{H}_{2} \mathrm{O}_{2}\right)$ without addition of potassium iodide $(\mathrm{KI})$ in simulated $\mathrm{CSO}(5 \%$ wastewater $)$

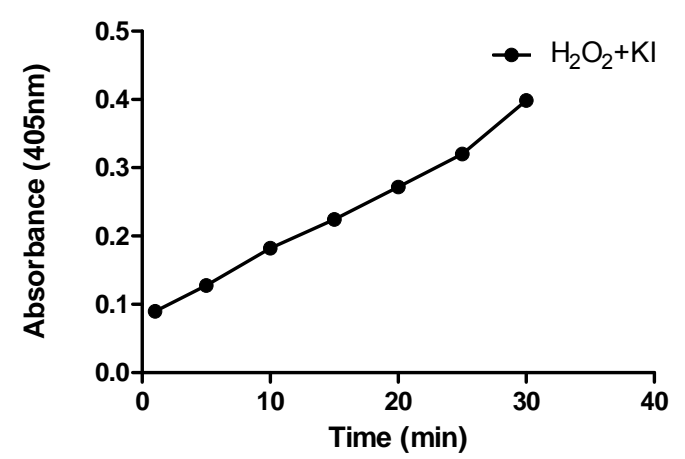

Figure S4: Absorbance of ABTS at $405 \mathrm{~nm}$ when oxidised by $2.5 \mathrm{mg} \cdot \mathrm{L}^{-1}$ hydrogen peroxide $\left(\mathrm{H}_{2} \mathrm{O}_{2}\right)$ with addition of potassium iodide $(\mathrm{KI})$ in simulated CSO ( $5 \%$ wastewater) 

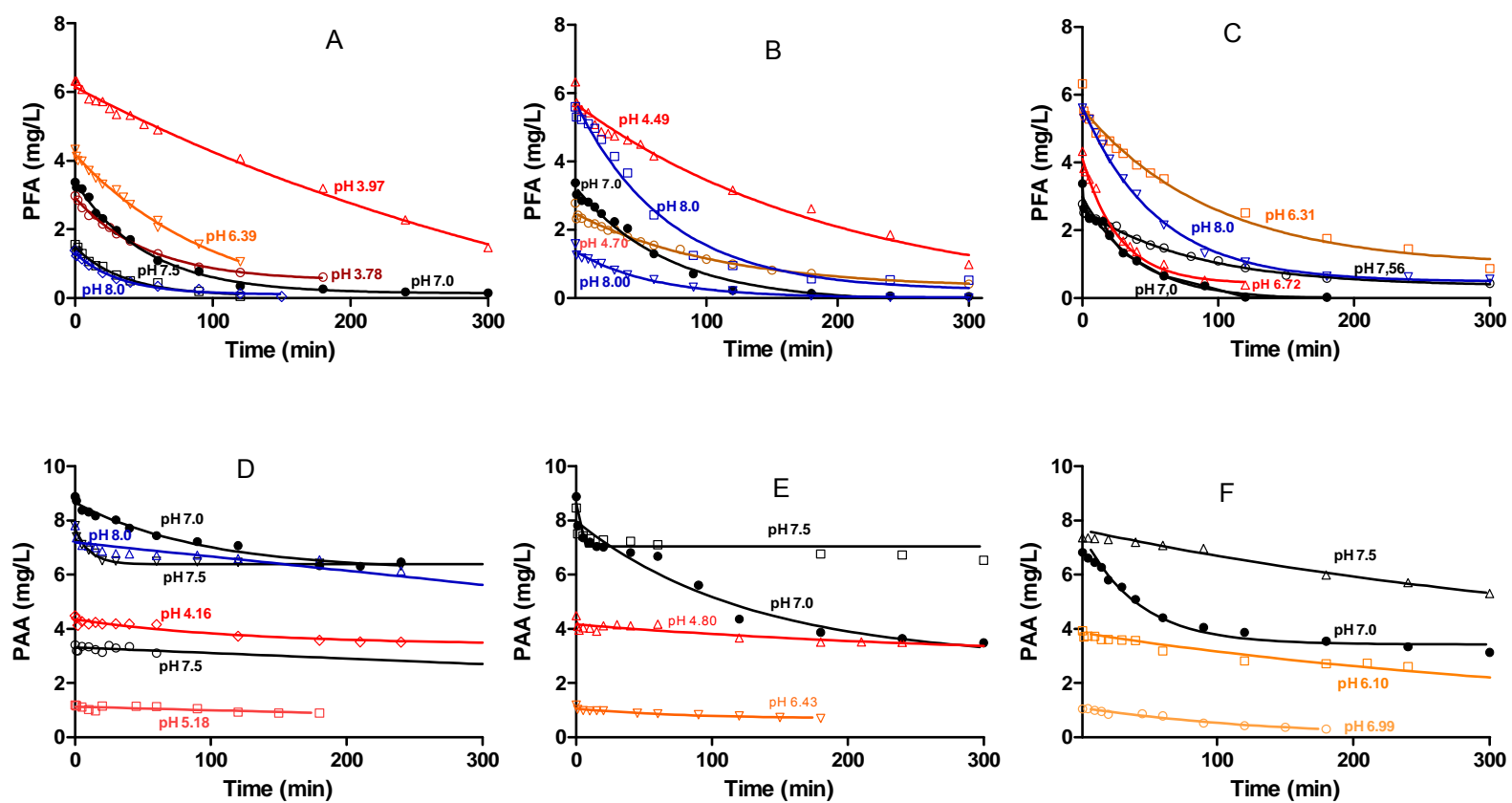

Figure S5: Concentration profiles of PFA at different $\mathrm{pH}$ in simulated extended overflow (5\% wastewater) (graph A), in typical overflow (15\% wastewater) (graph B) and in first flush ( $40 \%$ wastewater) (graph C). Graph D, E and F shows the concentration profiles of PAA at different $\mathrm{pH}$ in simulated extended overflow (5\% wastewater), in typical overflow (15\% wastewater) and in first flush (40\% wastewater) respectively. Concentration profiles with open symbols were conducted in wastewater collected from Lundtofte wastewater treatment plant and concentration profiles with closed symbols were conducted in wastewater collected from the sewage pipe at Tune CSO structure.

\section{Section 3: Disinfection efficiency}

Figure S6 shows the disinfection efficiency of PAA and PFA in different simulated CSOs. Disinfection effectiveness of different concentrations of organic peroxides on different indicator organisms in extended CSO simulated with 5\% wastewater in different contact time was shown in graph A and B. Matrix influence on disinfection efficiency of peracetic acid with different contact time for enterococcus illustrated by 2 simulated CSO qualities was shown in graph $\mathrm{C}$ and $\mathrm{D}$. The effect of initial concentration of performic acid and contact time on E. coli and enterococcus in extended CSO simulated with 5\% wastewater was shown in graph $\mathrm{E}$ and $\mathrm{F}$. The matrix influence on disinfection efficiency of performic acid with different contact time for enterococcus illustrated by 2 simulated CSO qualities was shown in graph $\mathrm{G}$ and $\mathrm{H}$. 
E. coli (5\% wastewater)



Enterococcus (15\% wastewater)

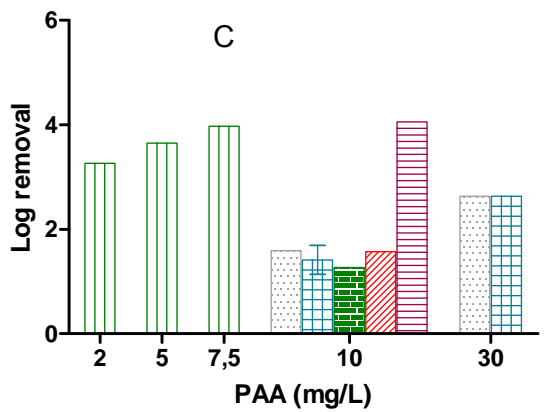

E. coli (5\% wastewater)

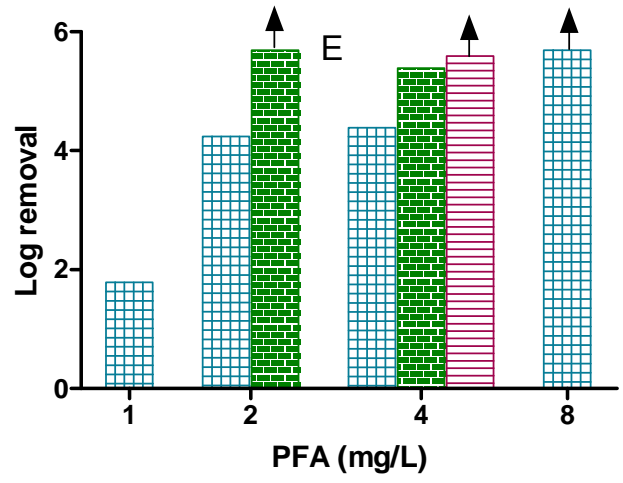

Enterococcus ( $15 \%$ wastewater)

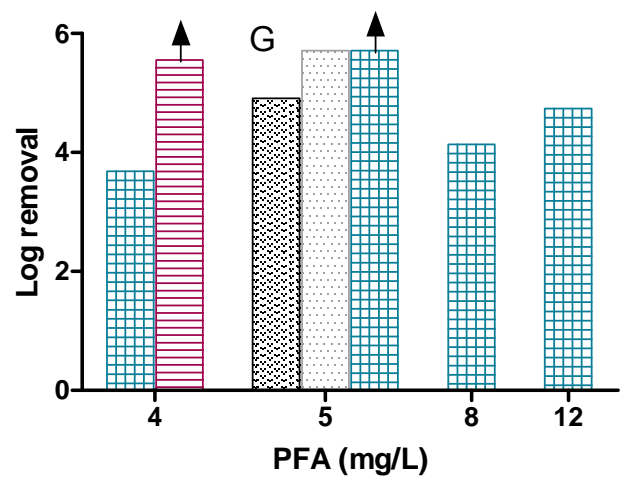

Enterococcus (5\% wastewater)

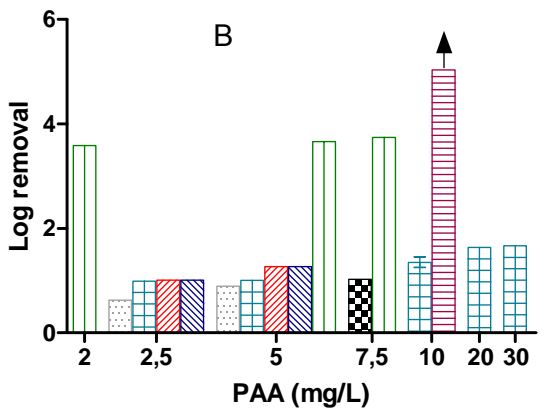

$5 \mathrm{~min}$

D $7 \mathrm{~min}$

四 $10 \mathrm{~min}$

臣 $20 \mathrm{~min}$

שाn $30 \mathrm{~min}$

$60 \mathrm{~min}$

曰 $240 \mathrm{~min}$

سण $360 \mathrm{~min}$

\section{Enterococcus (40\% wastewater)}

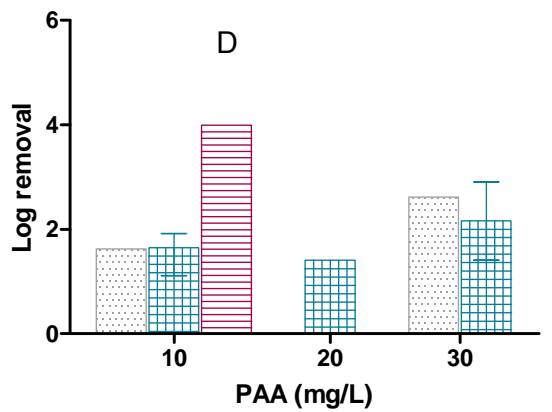

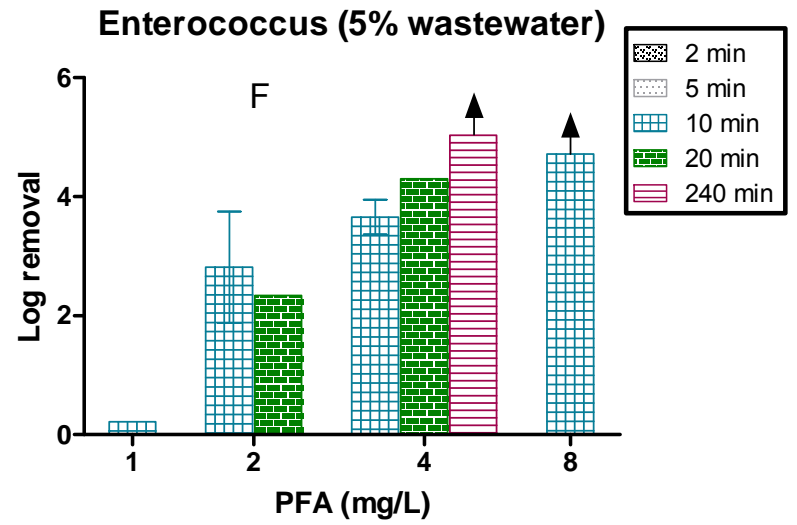

Enterococcus (40\% wastewater)

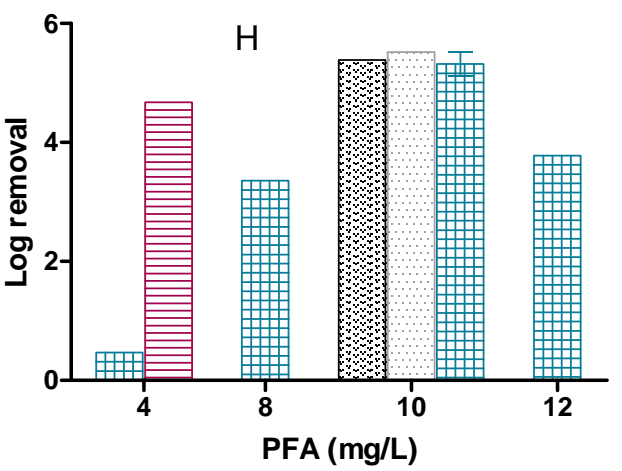

Figure S6: Disinfection efficiency of PAA and PFA in different simulated CSOs. Graph A/B shows disinfection effectiveness of different concentrations of organic peroxides on different indicator organisms in extended CSO simulated with $5 \%$ wastewater in different contact time. Graph C/D shows the matrix influence on disinfection efficiency of peracetic acid with different contact time for enterococcus illustrated by 2 simulated CSO qualities. Graph E/F 
illustrates the effect of initial concentration of performic acid and contact time on E. coli and enterococcus in extended CSO simulated with $5 \%$ wastewater. Graph $\mathrm{G} / \mathrm{H}$ shows the matrix influence on disinfection efficiency of performic acid with different contact time for enterococcus illustrated by 2 simulated CSO qualities. The T-bars indicates the range of the mean of results when the treatment was repeated on different days and " $\mathbf{\Delta}$ " indicated the log removal is greater than the value shown by the bar as the indicator organism MPN was below the detection limit after the treatment.

\section{Section 4: Toxicity}

Table 66 shows the toxicity effect ( $\mathrm{EC}_{10}$ and $\mathrm{EC}_{50}$ values) of PAA, PFA and $\mathrm{H}_{2} \mathrm{O}_{2}$ measured with the bacterial bioluminescence of Vibrio fischeri.

Table S6: $\mathrm{EC}_{10}$ and $\mathrm{EC}_{50}$ values of PAA, PFA and $\mathrm{H}_{2} \mathrm{O}_{2} .95 \%$ confidence intervals are indicated in brackets.

\begin{tabular}{c|cc}
\hline Chemicals $(\mu g / L)$ & $E C_{10}$ & $E C_{50}$ \\
\hline PAA & $78(60-102)$ & $109(90-130)$ \\
PFA & $\sim 341$ (wide) & $\sim 376$ (wide) \\
$\mathrm{H}_{2} \mathrm{O}_{2}$ & $\sim 11,000$ (wide) & $\sim 12,000$ (wide) \\
\hline
\end{tabular}

